Policy Research Working Paper 1936

Determinants of Transient Banchroncicantransent and Chronic Poverty

poverty are reduced by

greater command over

physical capital, and life-

Evidence from Rural China

cycle effects for the two types

of poverty are similar. But

there the similarities end.

Jyotsna Jalan

Most policies aimed at

Martin Ravallion

reducing chronic poverty may

have little or no effect on

transient poverty.

The World Bank

Research Development Group

June 1998 
Policy Research Working Paper 1936

\section{Summary findings}

Are the determinants of chronic and transient poverty different? Do policies that reduce transient poverty also reduce chronic poverty?

Jalan and Ravallion decompose measures of household poverty into chronic and transient components and use censored conditional quantile estimators to investigate the household and geographic determinants of both chronic and transient poverty, taking panel data for post-reform rural China.

They find that a household's average wealth holding is an important determinant for both transient and chronic poverty.

Although household demographics, levels of education, and the health status of members of the household are important for chronic poverty, they are not significant determinants of transient poverty.

Both chronic and transient poverty are reduced by greater command over physical capital, and life-cycle effects for the two types of poverty are similar. But there the similarities end.
Smaller and better-educated households have less chronic poverty, but household size and level of education matters little for transient poverty. Living in an area where health and education are better reduces chronic poverty but appears to be irrelevant to transient poverty. Nor are higher foodgrain yields a significant determinant of transient poverty, although they are highly significant in reducing chronic poverty.

These findings suggest that China's poor-area development program may be appropriate for reducing chronic poverty but is unlikely to help reduce variations in consumption that households typically face in poor areas - the exposure to uninsured income risk that underlies transient poverty will probably persist.

Other policy instruments may be needed to deal with transient poverty, including seasonal public works, credit schemes, buffer stocks, and insurance options for the poor.

This paper - a product of the Development Research Group- is part of a larger effort in the group to reexamine the role of the informal sector. Copies of the paper are available free from the World Bank, 1818 H Street NW, Washington, DC 20433. Please contact Patricia Sadar, room MC3-632, telephone 202-473-3902, fax 202522-1153, Internet address psader@worldbank.org. The authors may be contacted at jjalan@worldbank.org or mravallion@worldbank.org. June 1998. (22 pages)

The Policy Research Working Paper Series disseminates the findings of work in progress to encourage the exchange of ideas about development issues. An objective of the series is to get the findings out quickly, even if the presentations are less than fully polished. The papers carry the names of the authors and should be cited accordingly. The findings, interpretations, and conclusions expressed in this paper are entirely those of the authors. They do not necessarily represent the view of the World Bank, its Executive Directors, or the countries they represent. 


\title{
Determinants of Transient and Chronic Poverty: Evidence from Rural China
}

\author{
Jyotsna Jalan and Martin Ravallion ${ }^{1}$
}

' Development Research Group, World Bank, 1818 H Street NW, Washington DC, 20433. James Powell made a helpful suggestion regarding the estimation procedure. The financial support of the World Bank's Research Committee (under RPO 678-69) is gratefully acknowledged. 


\section{$1 \quad$ Introduction}

Some of the poverty observed at one date is bound to be a temporary state due to a shortlived drop in individual levels of living; call this "transient poverty". For other poor households at one date, their poverty arises from low long-term welfare - "chronic poverty". Different policies may well be called for in addressing these two types of poverty. Longer term investments in the poor, like increasing their human and physical assets, or the returns to those assets, are likely to be more appropriate for chronic poverty. On the other hand, insurance and incomestabilization schemes which protect households against idiosyncratic economic shocks would appear be more important when poverty is transient. ${ }^{2}$

The data typically used to inform discussions on how to fight poverty are based on the correlations found in a single cross-sectional household survey. ${ }^{3}$ Such data do not allow us to differentiate these two types of poverty. So we cannot say from the data normally available how much poverty is transient versus chronic. Nor can we say whether the two types of poverty are caused differently; possibly quite similar processes are at work in creating both types of poverty, and (hence) that the same policies will help against both.

This paper tests whether different processes are at work in determining transient versus chronic poverty. We propose and implement an approach to measuring and modeling both components of poverty. Transient poverty is defined as the contribution of consumption variability to expected poverty over time. The chronic component is the poverty which remains when inter-temporal variability in consumption has been smoothed out. In analyzing these two

\footnotetext{
${ }^{2}$ For a description of alternative policy instruments, see Lipton and Ravallion (1995, Section 6).

3 See World Bank $(1990,1996)$ for overviews of such "poverty profiles".
} 
components we use censored conditional quantile estimation methods which (unlike the popular Tobit estimator) are robust to distributional misspecifications of the error term.

We use data from four provinces - Guangdong, Guangxi, Guizhou and Yunnan - in southwest rural China for the period 1985-90. During this period, about half of the average severity of poverty (as measured by the squared poverty gap index, which we define later) was directly attributed to inter-temporal variability in consumption (Jalan and Ravallion, 1998a). There is also evidence of significant exposure to income risk in this setting (Jalan and Ravallion, 1998b). So transient poverty would appear to be a serious concern.

However, China's anti-poverty strategy has given far more emphasis to fighting chronic poverty than transient poverty. The main policy intervention has been the national poor area development program. ${ }^{4}$ This program aims to reduce poverty by promoting income-generating investments in local agriculture and rural development, rather than short-term insurance or statecontingent transfers. The program puts considerable emphasis on raising farm yields, particularly of foodgrain yields. Given the evidence of significant exposure to income risk and transient poverty in this setting, the question for policy is whether such efforts are adequate for combating both transient and chronic poverty.

The following section describes our measures of transient and chronic poverty. Section 3 describes the estimation methods for modeling the determinants of measured poverty at the household level. Our data are described briefly in Section 4 . We present and discuss the estimation results in Section 5. Conclusions are found in Section 6.

${ }^{4}$ For further discussion of this program see Leading Group (1988), World Bank (1992), and Jalan and Ravallion (1998c), 


\section{Transient and chronic measures of poverty}

We first describe our decomposition in general terms, before discussing the specific measure we will use. Let $\left(y_{i l}, y_{i 2}, \ldots, y_{i D}\right)$ be household $i$ 's (positive) consumption stream over $D$ dates. We assume that consumptions have been normalized for differences in demographics and prices, such that $y_{i t}$ is an agreed metric of household welfare. Let $P\left(y_{i l}, y_{i 2}, \ldots, y_{i D}\right)$ be an aggregate inter-temporal poverty measure for household $i$. Following Ravallion (1988), we define the transient component $\left(T_{i}\right)$ of $P($.$) as the portion which is attributable to inter-temporal variability in$ consumption:

$$
T_{i}=P\left(y_{i 1}, y_{i 2}, \ldots, y_{i D}\right)-P\left(E y_{i}, E y_{i}, \ldots, E y_{i}\right)
$$

where $E y_{i}$ is the expected value of consumption over time ("time-mean consumption") for household $i$. The chronic component $\left(C_{i}\right)$ is

$$
C_{i}=P\left(E y_{i}, E y_{i}, \ldots, E y_{i}\right)
$$

The inter-temporal poverty measure is the sum of the chronic and transient components.

We impose a number of conditions on the poverty measure. We require that the measure be additive. ${ }^{5}$ In this case, that means both additive over time and across households. We assume that the individual poverty function $p\left(y_{i t}\right)$ is the same for all households and dates; in principle, one could choose appropriate deflators for consumptions to make this assumption reasonable. The function $p$ is also taken to be strictly convex and decreasing up to the poverty line and zero

${ }^{5}$ On the arguments in favor of additivity see Foster and Shorrocks (1991). 
thereafter and we assume that the measure vanishes continuously as one approaches the poverty line from below. Convexity assures that the measure satisfies the "transfer axiom", in that it penalizes inequality amongst the poor. Having the measure vanish smoothly at the poverty line rules out "kinks" in measured individual poverty as the poverty line is crossed.

The main empirical poverty measure we use is the squared poverty gap (SPG) index of Foster et al., (1984). The SPG for household $i$ is:

$$
\begin{aligned}
p\left(y_{i t}\right) & =\left(1-y_{i t}\right)^{2} \text { if } y_{i t}<1 \\
& =0 \text { otherwise }
\end{aligned}
$$

where $y_{i t}$ is normalized by the (possibly household-specific) poverty line and thus takes the value

of unity for someone at the poverty line. The aggregate SPG is the household-size weighted mean of $p\left(y_{i t}\right)$ across the whole population. Unlike the head-count index (proportion of people below the poverty line) or poverty gap index (mean proportionate distance below the line), the squared poverty gap penalizes inequality amongst the poor (Foster, et. al., 1984).

\section{$3 \quad$ Estimating transient and chronic poverty models}

Having defined transient and chronic poverty at the household level, we want to examine whether the household and geographic characteristics that one would typically identify as important in determining chronic poverty also influence the extent of transient poverty. Is there any evidence in our data that different household and/or county characteristics have different effects on the two components of poverty, or do their effects tend to be congruent? 
To answer this question, we estimate two models where we regress the measures of transient and chronic poverty respectively on the same set of household and county characteristics. Our model of transient poverty is:

$$
\begin{aligned}
T_{i} & =T_{i}^{*} \text { if } T_{i}^{*}>0 \text { where } T_{i}^{*}=x_{i}^{\prime} \beta^{T}+u_{i}^{T} \\
& =0 \text { otherwise }
\end{aligned}
$$

where $T_{i}^{*}$ is a latent variable, $T_{i}$ is the observed transient poverty, $\beta^{\mathrm{T}}$ is a $\mathrm{kx} 1$ vector of unknown parameters, $x_{i}$ is a $k x 1$ vector of explanatory variables, and $u^{T}$ are the model residuals. The analogous model for chronic poverty is given by:

$$
\begin{aligned}
C_{i} & =C_{i}^{*} \text { if } C_{i}^{*}>0 \text { where } C_{i}^{*}=x_{i}^{\prime} \beta^{C}+u_{i}^{C} \\
& =0 \quad \text { otherwise }
\end{aligned}
$$

In the standard poverty literature, it is common practice to use censored regression. estimation techniques like the Tobit models, where the underlying error distribution is assumed to be normally distributed, to estimate specifications such as (4) and (5). However, Tobit estimates are not robust to misspecifications in the error distribution-estimates are both inconsistent and inefficient in the presence of heteroscedasticity and/or non-normality in the errors. ${ }^{6}$

Recognizing the fragility of the "Tobit" type estimators, we use semi-parametric methods

${ }^{6}$ Arabmazar and Schmidt (1982) provide Monte-Carlo evidence on the fragility of Tobit models under distributional misspecifications. One could assume different non-normal parametric distributions such as a Burr Type II, Weibull etc. for the underlying error term to explicitly incorporate heteroscedasticity and non-symmetric behavior. However, economic theory rarely suggests the choice of a particular parametric distribution over another. 
to estimate our transient and chronic poverty specifications. ${ }^{7}$ Such methods are robust in that the only assumptions required for consistency of the non-intercept coefficients are that the errors be independently and identically distributed, and continuously differentiable with positive density at the chosen quantile. ${ }^{8}$ The minimization function for our model of transient poverty (a similar model is estimated using the chronic poverty measure) is

$$
Q_{n}(\beta ; \theta)=\frac{1}{N} \sum_{i=1}^{N} \rho_{\theta}\left|T_{i}-\max \left(0, x_{i}^{\prime} \beta^{T}\right)\right|
$$

which is minimized over all $\beta$ in the parameter space where $\rho_{\theta}$ is a weighting function used to "center" the data, depending on the quantile $\theta$. That is, $\rho_{\theta}(\lambda) \equiv[\theta I(\lambda \geq 0)+(1-\theta) I(\lambda<0)]|\lambda|$, where I(.) is an indicator function. ${ }^{9}$

Notice that under our inter-temporal additivity assumption (section 2), one could instead model the date-specific transient poverty measure, $T_{i t}=p\left(y_{i l}\right)-p\left(E y_{i}\right)$. However, this would add greatly to the complexity of the econometrics and for no obvious gain. Consider, for example, an event which lowers consumption of the poor this year, but their consumption bounces back fully next year. This will clearly contribute to transient poverty, and that will show up in our regression

${ }^{7}$ In recent years, several semiparametric methods like Powell's Censored Quantile Regression (CQR) models $(1984,1986)$, Horowitz's $(1986,1988)$ Semiparametric Generalized Least Squares (SGLS) estimator, etc. have been proposed to overcome the problem of non-robustness of the maximum likelihood estimators to distributional misspecifications. In this paper, we use Powell's CQR estimators.

8 The censored least absolute deviation models (CLAD), where the distribution is "centered" around the median is a special case of the censored quantile regression (Powell, 1984). However, CLAD is not always applicable (as we discuss below) and thus we use the CQR method.

${ }^{9}$ The model is estimated using the QREG command in STATA (Version 5.0) and a suggestion by Buchinsky (1992). 
analysis. However identifying this effect in regressions for $T_{i t}$ will requite a complex dynamic panel data model (with the censoring handled semi-parametricly), and there would be little advantage of the added complexity in estimation, since we can already identify the effect with our simpler measure.

\section{Data and Descriptive Statistics}

We shall use a panel data set constructed from the Rural Household Budget Surveys (RHS) done by China's State Statistical Bureau (SSB). The RHS has been a well-designed and executed budget survey of a random sample of households drawn from a sample frame spanning rural China (including small-medium towns), and with unusual effort made to reduce non-. sampling errors. ${ }^{10}$ Sampled households keep a daily record of all transactions, as well as $\log$ books on production. Interviewing assistants visit each sampled household every two weeks to check on their progress and collect the data. Checks are made at the county statistical office, with return visits to the households when necessary. The consumption data obtained from such an intensive survey process are almost certainly more reliable than those obtained by the common cross-sectional surveys in which the consumption data are based on recall at a single interview.

The household data are collated with geographic data at the village, county and the province levels. At the village level, we have data on topography (whether village is in plains, or in hills, or in mountains), on location (whether it is in a coastal area), ethnicity (whether it is a minority village or not), and whether the village is in a revolutionary base area (areas where the

\footnotetext{
${ }^{10}$ Chen and Ravallion (1996) provide a fairly complete discussion of how the survey was done.
} 
Communist Party had established its bases prior to 1949). At the county level we have a much larger database drawn from county administrative records. At the province level we simply include dummy variables for the province. All nominal values have been normalized by 1985 prices.

We construct measures of chronic and transitory poverty using a sample of 5,854 households over the six-year period 1985-90 from four contiguous provinces in southern China, namely Guangdong, Guangxi, Guizhou, and Yunnan. Three of the provinces (Guangxi, Guizhou and Yunnan) form a region of south-west China which is widely regarded as one of the poorest regions in the country. Guangdong, on the other hand, is a relatively rich coastal region. For example, in 1990, using the squared poverty gap measure, the severity of poverty in Guizhou was estimated to be $3.26 \%$ compared to less than $0.15 \%$ in Guangdong.

In our subsequent analysis, we use the squared poverty gap as our measure of poverty (Foster et. al., 1984). Our poverty estimates are based on consumption expenditure per capita as the individual welfare measure. The consumption measure is comprehensive, in that it includes imputed values for consumption from own production valued at local market prices, and it also includes an imputed value of the consumption streams from the inventory of consumer durables. ${ }^{11}$

The poverty lines are those constructed for these provinces of rural China by Chen and Ravallion (1996). These are based on a normative food bundle set by SSB, which assures that average nutritional requirements are met with a diet which is consistent with Chinese tastes; this

"Certain problems have been corrected in the raw data. Grain consumption from own production has been valued at market rather than administrative prices, current year housing expenditure has been replaced with $5 \%$ of the recorded dwelling value, and $10 \%$ of the estimated current value of the durable goods has been used to compute current spending on durable good; see Chen and Ravallion (1996) for further details. 
is valued at province-specific prices. The food component of the poverty line is augmented with an allowance for non-food goods, consistent with the non-food spending of those households whose food spending is no more than adequate to afford the food component of the poverty line.

Table 1 reports the chronic and transient poverty measures for the four provinces in our sample. Among the four provinces, Guizhou is the poorest in terms of squared poverty gap measure, and has the highest percentage of chronic poverty. Guangdong has the smallest percentage of total poverty but also the highest proportion of transient poverty in total poverty. ${ }^{12}$

Table 2 reports descriptive statistics on household and geographic characteristics for the sample of households used in the analysis. On average, the sample is fairly well represented across the four provinces. About a third of the adults in the household are on average illiterate. This is also reflected in the proportion of illiterates in the $15^{+}$population at the county level. There are only a few households with members working in non-farm sector i.e. in the state sector or in TVEs. The average consumption is 342.19 yuan while the average income of the households in the sample is 446.31 yuan.

\section{Results}

\section{$5.1 \quad$ Explanatory Variables}

The World Bank's (1992) study "China: Strategies for Reducing Poverty in the 1990's", claims the correlates of absolute poverty to be remote and mountainous areas, limited transport, power and other rural infrastructure. They also find that minority communities and households gap.

${ }^{12}$ We observe a similar trend if we use the poverty gap measure instead of the squared poverty 
disadvantaged by illiteracy, ill-health constitute a disproportionate share of the poor.

The question here is whether the determinants of poverty identified by studies such as World Bank (1992) are also important in explaining each of the two components of poverty. To answer this question we include as explanatory variables household-specific human and physical assets, and community effects, the latter measured by a set of county specific variables. ${ }^{13}$

The household variables include: schooling variables (the proportion of adult household members with different levels of schooling (left out category is those with high school or higher levels of education), proportion of children (defined as household members under 15 years of age) with primary and secondary school education (left-out category is the proportion staying at home or are declared to be illiterate); a wide range of demographic variables to asses whether chronically and transitory poor households share the same demographic characteristics (age and age $^{2}$ of the household head to capture any life-cycle effects, the proportion of kids in the household at various ages with the proportion of children under infants 5 years as the left out category, and dummies for different household sizes, with the left-out category being a household with no kids). Rural labor markets appear to be thin in this setting, so demographic characteristics of the household can matter to productivity; these variables may also pick up differences in consumption behavior. ${ }^{14}$

In addition to human capital, access to land and physical capital are likely to be important factors in escaping poverty. We include land holding, and grain yield per acre (as an indicator of

13 We also estimate an alternative model where the county variables are replaced by a set of county dummies (there are 131 counties in the sample).

${ }^{14}$ Demographic characteristics of the poor are often found to be significantly different . 
land quality and shocks to farm output). To control for the variance in yields for an individual household, we have also included the household specific standard deviation of grain yield. Household wealth is also hypothesized to be a determinant of chronic and/or transitory poverty. ${ }^{15}$ Households with their own resources will need less credit to smooth consumption. And if they need to borrow, they will probably be in a better position to do so.

The geographic variables are dummies for the topographical features of the county of residence (plains, coast, and mountains), dummy variables for whether the county falls into a specific need-based category (revolutionary base area, minority area or border area), illiteracy rate in the county among the $15^{+}$population, availability of medical facilities, and employment opportunities in the non-farm sector, population density of the county, and province dummies for Guangdong, Guizhou and Yunnan (left-out province dummy is Guangxi) ${ }^{16}$

\section{$5.2 \quad$ Results}

Using the upper poverty line (Chen and Ravallion, 1996), there are 1,136 households in our sample with some chronic poverty and 3,084 households with some transient poverty. Given the high-degree of censored observations (non-chronic poor households for whom the chronic poverty measure takes a value zero), the conditional quantile model has to be estimated at least at the $90^{\text {th }}$ quantile. However, while the higher quantile model is more informative in estimating the model parameters, the estimates themselves are less precise at a higher quantile because fewer observations are used in the estimation process. To circumvent this problem, we have used 1.5

is Wealth is defined as the sum of the values of fixed productive assets, cash, deposits, housing, grain stock, and stock of durables, all at year end.

16 We do not include a dummy for the coastal area in the chronic poverty model because only 36 of the 3,964 chronically poor households in the sample reside in the coastal area. 
times the poverty line as our "new" poverty line to determine whether households are chronic poor or transient poor. Using the inflated poverty line, there are 3,964 households with some chronic poverty and 5,212 households with positive transient poverty. We estimate the models at the $70^{\text {th }}$ quantile. ${ }^{17}$ The variance-covariance matrix of the parameter estimates are computed using bootstrap re-sampling techniques. ${ }^{18}$

Are the determinants of transient and chronic poverty congruent? Tables 3 reports the parameter estimates for the two poverty measures respectively. The model predicts transient poverty less well than chronic poverty (as can be seen from the pseudo $\mathrm{R}^{2}$ ). ${ }^{19}$ The estimates in Table 3 suggest that the most important set of variables determining transient poverty are the household's stage of life cycle, wealth holdings and the standard deviation of the household's wealth holdings and cultivated land holdings. There is some evidence of life-cycle events being important in determining transient poverty which falls up to about 45 years of age, and rises after that. While higher physical wealth tends to decrease transient poverty, greater volatility in a household's wealth holdings is likely to increase it. There is little sign that education reduces transient poverty, and very few of the other demographic and county characteristics seem to be

${ }^{17} \mathrm{We}$ also estimate the models at $75^{\text {th }}$ and $85^{\text {th }}$ quantiles. The qualitative results are very similar to those obtained for the $70^{\text {th }}$ quantile and are available from the authors on request.

${ }^{18}$ This is because STATA's QREG command estimates the variance-covariance matrix of the coefficients using a method proposed by Koenker and Basset (1982). However, Rogers (1992) and Gould (1992) argue that, while this method works adequately under the assumption of homoscedastic errors, it underestimates the standard errors in the presence of heteroscedasticity.

19 The pseudo- $\mathrm{R}^{2}$ is calculated in STATA as 1 - ratio of the sum of the weighted deviations about estimated quantile to the sum of the weighted deviations about the raw quantile. 
important factors. ${ }^{20}$

As one would expect, demographic characteristics (e.g., household size, education levels of the head of the household, of the kids and the labor force of the household, and agecomposition of the kids in the household) seem to be more important for chronic poverty than for transient poverty. Higher variability in grain yield is associated with higher chronic poverty. This suggests that households exposed to higher yield risk-presumably associated with adverse local geo-climatic conditions-tend to have lower long-term consumption levels after controlling for a wide range of other household characteristics. Risk-market failures may well be spilling over to diminish longer-term productivity. ${ }^{21}$

Higher physical wealth reduces transient poverty as well as chronic poverty. However, while higher variance in physical wealth increases transient poverty, it reduces chronic poverty. Finally, households with higher cultivated land per capita are less vulnerable to chronic poverty.

The above results suggest that the determinants of total poverty reported in the literature (for example, World Bank, 1992) are determinants of chronic poverty. However, the determinants of transient poverty measure are quite different-only physical assets are important. For example, while our results confirm that higher foodgrain yields - a key instrument for fighting

20 The only household demographic variable which is significant is the proportion of kids in the age group 6-11 years, and 12-14 years. This means that relative to kids in the 0-5 years category (left out category), households with kids in the 6-11 and 12-14 years group are less likely to be transient poor. Also households where the kids have at least secondary school education (relative to they being illiterate and/or staying at home) are less likely to be transient poor. The only county variable which is significant is the dummy for mountains-households in mountainous areas are more likely to be transient poor. While the number of transient poor is likely to be smaller in Guangdong relative to Guangxi, in both Yunnan and Guizhou, the population is more likely to be in transient poverty relative to Guangxi.

${ }^{21}$ For arguments along these lines and supportive evidence in other settings see Rosenzweig and Binswanger (1993), Rosenzweig and Wolpin (1993), and Chaudhuri (1994). 
poverty identified by China's current poor area development program - reduce chronic poverty, they are not a significant determinant of transient poverty.

We also estimated the transient and chronic poverty models using the commonly used Tobit method under different parametric distributional assumptions-Burr Type II (allow for population heterogeneity and non-symmetric error distribution), standard Tobit (normal), and logistic distributions. ${ }^{22}$ While the results were qualitatively similar between the parametric and the semi-parametric models, the question is whether statistically the parametric model describes the data better than the semi-parametric models or vice-versa. To answer this we tested the parametric models against the semi-parametric model using the tests described in Newey (1987). The test statistic is asymptotically distributed as a chi-square and is of the standard Hausman form. The parametric models were were rejected for almost all our specifications in favor of the semi-parametric model. ${ }^{23}$

\section{Conclusions}

Using a time series of consumptions at household level, we have measured the extent of transient poverty as the amount of poverty ascribed to variability of consumptions over time.

${ }^{22}$ The results across the three parametric distributions for both the transient and chronic poverty models were qualitatively very similar with some exceptions, details of which are available from the authors on request. Using a simple likelihood-ratio test suggested by Horowitz and McAleer (1988) to test the general parametric model against the non-nested parametric alternative, we found that both the Burr Type II and the logistic specifications were rejected in favor of the Tobit model in our sample. The pagan-Vella (1989) test however rejected both the normality and the heteroscedasticity assumptions of the standard normal Tobit specification for both the transient and the chronic poverty models.

${ }^{23}$ Details on the construction of the test and the individual test statistics are available from the authors on request. 
Chronic poverty is measured by the amount of poverty in the distribution of time-mean consumptions. We have then investigated the household and geographic correlates of each component separately using semi-parametric censored regression methods.

We find that both chronic and transient poverty are reduced by greater command over physical capital; and life-cycle effects are similar between the two types of poverty. However, the similarities end there. While smaller and better educated households have lower chronic poverty, these things matter little to transient poverty. And living in an area with better attainments in health and education reduces chronic poverty but appears to be irrelevant to transient poverty. Higher foodgrain yields are not a significant determinant of transient poverty, though they are highly significant in reducing chronic poverty.

Our results suggest that different models are determining chronic versus transient poverty in this setting. Variables which are typically identified as being determinants of total poverty are also found to be variables which are important in determining chronic poverty. However, few of these are found to be significant in the transient poverty model.

The findings in our paper also suggest that while China's poor area development program may well be an appropriate policy response to chronic poverty, it is unlikely to help much in reducing the variability in consumption that households typically face in this setting. Exposure to uninsured income risk that underlies the high transient poverty will probably persist. In such cases other policy instruments like seasonal public works, credit schemes, buffer stocks, and insurance options for the poor to smooth variability in income and/or consumption may well be needed. 


\section{References}

Arabmazar, A. and P. Schmidt (1982), "An investigation of the robustness of the Tobit estimator to non-normality," Econometrica, 50, 1055-1063.

Buchinsky, M. (1994),"Changes in the U.S. Wage Structure 1963-87: Application of Quantile Regression", Econometrica, 62, 405-458.

Chaudhuri, Shubham (1994) "Crop Choice, Fertilizer Use, and Credit Constraints: An Empirical Analysis", mimeo, Department of Economics, Colombia University.

Chen, Shaohua and Martin Ravallion (1996), "Data in Transition: Assessing Rural Living Standards in Southern China", China Economic Review, 7, 23-56.

Foster, James., J. Greer, and Erik Thorbecke (1984), "A Class of Decomposable Poverty Measures", Econometrica 52: 761-765.

Foster, J., and Shorrocks A. (1991). "Subgroup Consistent Poverty Indices", Econometrica 59: 687-709.

Gould, W. W. (1992), "Quantile regression with bootstrapped standard errors" Stata Technical Bulletin, 9: 19-21.

Horowitz, J. (1986), "A distribution-free least squares estimator for censored linear regression models," Journal of Econometrics, 32, 59-84.

Horowitz, J. (1988), "Semiparametric M-estimation of censored linear regression models," in Advances in Econometrics: Nonparametric and Robust Inference, Volume 7.

Horowitz, J. and M. McAleer (1988), “A simple method for testing a general parametric model against a non-nested alternative," Working Paper No. 166, Australian National University.

Jalan, Jyotsna and Martin Ravallion (1998a), "Transient Poverty in Post-Reform Rural China", 
Journal of Comparative Economics, forthcoming.

Jalan, Jyotsna and Martin Ravallion (1998b), "Are the Poor Less Well Insured? Evidence on Vulnerability to Income Risk in Rural China", Journal of Development Economics, forthcoming.

Jalan, Jyotsna and Martin Ravallion (1998c), "Are There Dynamic Gains from a Poor Area Development Program?", Journal of Public Economics, 67: 65-85.

Koenker, R. And G. Bassett (1982), "Robust Tests for Heteroscedasticity based on Regression Quantiles", Econometrica, 50, 43-61.

Leading Group (1988), Outlines of Economic Development in China's Poor Areas. Beijing: Office of the Leading Group of Economic Development in Poor Areas Under the State Couñcil, Agricultural Publishing House.

Lipton, Michael and Martin Ravallion (1995), "Poverty and policy", in: Jere Behrman and T.N. Srinivasan eds., Handbook of Development Economics, Volume III, North Holland, Amsterdam.

Newey, W. K. (1987), "Specification Tests for Distributional Assumptions in the Tobit Model," Journal of Econometrics, 34, 125-145.

Pagan, A. R. and F. Vella (1989), "Diagnostic tests for models based on individual data: A survey," Journal of Applied Econometrics, 4, S29-S59.

Powell, James L. (1984), "Least Absolute Deviations Estimation For the Censored Regression Model", Journal of Econometrics, 25, 303-325.

Powell, James L. (1986), "Censored Regression Quantiles", Journal of Econometrics, 32, 143-155. 
Ravallion, Martin (1988), "Expected poverty under risk-induced welfare variability", Economic Journal, 98, 1171-1182.

Rogers, W. (1992), "Quantile Regression Standard Errors", Stata Technical Bulletin, 9: 17-21.

Rosenzweig, Mark, and Hans Binswanger (1993), "Wealth, weather risk and the composition and profitability of agricultural investments", Economic Journal, 103, 56-78.

Rosenzweig, Mark, and Kenneth Wolpin (1993), "Credit market constraints, consumption smoothing, and the accumulation of durable production assets in low-income countries: Investments in bullocks in India", Journal of Political Economy, 101, 223-245.

World Bank (1990), World Development Report, World Bank, Washington DC.

World Bank (1992), China: Strategies for Reducing Poverty in the 1990s, World Bank, Washington DC.

World Bank (1996), Poverty Reduction and The World Bank: Progress and Challenges in the 1990s, World Bank, Washington DC. 


\section{Table 1: Decomposition of Observed Poverty into Transient and Chronic Components}

\begin{tabular}{lcccc}
\hline Province & $\begin{array}{c}\text { Observed } \\
\text { poverty }\end{array}$ & $\begin{array}{c}\text { Chronic poverty } \\
\text { component }\end{array}$ & $\begin{array}{c}\text { Transient poverty } \\
\text { component }\end{array}$ & $\begin{array}{c}\text { \% of observed poverty } \\
\text { which is transient }\end{array}$ \\
\hline Guangdong & 0.14194 & 0.02241 & 0.11953 & 84.21 \\
Guangxi & 1.78789 & 0.77543 & 1.01246 & 56.63 \\
Guizhou & 2.85365 & 1.63217 & 1.22148 & 42.80 \\
Yunnan & 1.15714 & 0.59045 & 0.56669 & 48.97 \\
\hline All 4 provinces & 1.42790 & 0.72272 & 0.70518 & 49.39 \\
\hline
\end{tabular}

Notes: The poverty measures reported in the table are the squared poverty measures for the province specific upper poverty line as described in Chen and Ravallion (1996). The poverty measures reported in the table are in percentages. 
Table 2: Descriptive Statistics

\begin{tabular}{lcc}
\hline Variable & $\begin{array}{c}\text { Sample } \\
\text { mean }\end{array}$ & $\begin{array}{c}\text { Sample } \\
\text { std. dev. }\end{array}$ \\
\hline Household size & 5.86 & 1.91 \\
Proportion of kids in the household & 2.22 & 1.34 \\
Proportion of kids with primary school education & 0.26 & 0.36 \\
Age of household head & 42.14 & 11.40 \\
Proportion of adults who are illiterate & 0.33 & 0.29 \\
Prop of adults who are primary school educated & 0.38 & 0.26 \\
Prop of households with members working in state sector & 0.04 & 0.20 \\
Prop of households with members working in TVEs & 0.02 & 0.15 \\
Mean consumption (yuan) & 342.19 & 188.59 \\
Mean income (yuan) & 446.31 & 296.22 \\
Grain yield (kgs per mu) & 265.55 & 111.50 \\
Wealth per capita (yuan) & 867.87 & 705.22 \\
Cultivated land per capita (mu) & 1.19 & 0.73 \\
Proportion of sample in minority area & 0.26 & 0.44 \\
Proportion of sample in plains & 0.22 & 0.41 \\
\% of illiterates in the 15 pop (county) & 35.24 & 15.73 \\
Medical personnel per 10,000 persons (county) & 8.00 & 4.94 \\
Pop empl in comm enterprises per 10,000 persons (county) & 117.21 & 67.88 \\
Proportion of sample in Guangdong & 0.22 & 0.41 \\
Proportion of sample in Guangxi & 0.31 & 0.46 \\
Proportion of sample in Guizhou & 0.24 & 0.42 \\
Proportion of sample in Yunnan & 0.23 & 0.42 \\
\hline Sample size & & 5,854 \\
\hline
\end{tabular}




\begin{tabular}{|c|c|c|c|c|}
\hline & \multicolumn{2}{|c|}{ Chronic poverty } & \multicolumn{2}{|c|}{ Transient poverty } \\
\hline & Coefficient & t-statistic & Coefficient & t-statistic \\
\hline Household size $(\log )$ & 5.094 & $7.324^{*}$ & -0.048 & -0.449 \\
\hline Household with couple \& child (dummy) & 0.665 & 0.324 & 0.135 & 0.332 \\
\hline Household with couple $\& 2$ children (dumrny) & 2.225 & 1.395 & -0.194 & $\ldots 0.049$ \\
\hline Household with couple $\& 3^{+}$children (dummy) & 3.951 & $2.438^{*}$ & 0.093 & 0.226 \\
\hline Three generation household (dummy) & 3.019 & $1.847^{*}$ & 0.180 & 0.449 \\
\hline Proportion of kids: $6-11$ years & -0.731 & -0.737 & -1.168 & $-4.804^{*}$ \\
\hline Proportion of kids: $12-14$ years & -5.234 & $-3.362^{*}$ & -0.621 & $-2.320^{*}$ \\
\hline Proportion of kids: $15-17$ years & -6.064 & $-3.451 *$ & -0.643 & $-1.905^{*}$ \\
\hline Age of household head & -0.305 & $-3.282^{*}$ & -0.038 & $-1.836^{*}$ \\
\hline Age $^{2}$ of household head & 0.003 & $2.592^{*}$ & 0.001 & $2.013^{*}$ \\
\hline Proportion of adults: illiterate & 2.107 & $2.048^{*}$ & 0.266 & 0.904 \\
\hline Proportion of adults: primary school educated & -1.149 & -1.096 & 0.215 & 0.757 \\
\hline Proportion of adults: secondary school educated & -2.333 & $-2.146^{*}$ & 0.255 & 0.857 \\
\hline Highest education of labor: illiterate (dummy) & $\mathbf{3 . 5 3 4}$ & $3.436^{*}$ & -0.074 & -0.376 \\
\hline Highest education of labor: primary school (dummy) & 2.686 & $3.785^{\star}$ & -0.047 & -0.373 \\
\hline Highest education of labor: middle school (dummy) & 2.301 & 3.358* & 0.082 & 0.728 \\
\hline Proportion of kids: primary school educated & -1.231 & $-2.791 *$ & 0.100 & 1.229 \\
\hline Proportion of kids: secondary school educated & -2.798 & $-2.236^{*}$ & -0.410 & $-2.539^{*}$ \\
\hline Whether h'hold mem works in state sector (dummy) & -4.521 & $-4.711^{*}$ & -0.202 & -1.073 \\
\hline Whether household member works in TVE's (dummy) & -0.999 & -0.937 & 0.040 & 0.153 \\
\hline Whether h'hold member works out of town (dummy) & -2.041 & $-2.215^{*}$ & 0.094 & 0.661 \\
\hline Mean grain yield $(x 10)$ & -0.220 & $-8.998^{*}$ & 0.001 & 0.132 \\
\hline Standard deviation of grain yield & 0.012 & $5 . .352 *$ & 0.001 & 1.580 \\
\hline Mean wealth per capita & -0.020 & $-31.957^{*}$ & -0.001 & $-15.959^{\star}$ \\
\hline Standard deviation of wealth per capita & -0.004 & $-2.624^{*}$ & 0.002 & $8.480^{*}$ \\
\hline Cultivated land per capita & -3.296 & $-10.834^{*}$ & -0.076 & -1.309 \\
\hline Plains (dummy) & -0.798 & -1.798 & -0.068 & -0.776 \\
\hline Coast (dummy) & - & - & -0.140 & -1.121 \\
\hline Mountains (dummy) & -0.928 & $-2.430^{*}$ & 0.218 & $2.401^{*}$ \\
\hline Revolutionary base area (dummy) & 2.846 & $3.736 *$ & 0.085 & 0.458 \\
\hline Border area (dummy) & -0.536 & -1.138 & 0.039 & 0.367 \\
\hline Minority area (dummy) & 0.701 & 1.779 & -0.038 & -0.429 \\
\hline Proportion of illiterates among the $15+$ in county & 0.060 & $3.499^{*}$ & 0.003 & 0.820 \\
\hline Medical persons per 10,000 population in county & -0.005 & -0.117 & 0.002 & 0.324 \\
\hline Proportion of pop employed in commercial enterprises & -0.005 & -1.563 & -0.000 & -0.376 \\
\hline Population density (log) & 0.286 & 0.520 & -0.024 & -0.242 \\
\hline Guangdong (dummy) & -8.566 & $-16.809^{*}$ & -0.440 & $-4.260^{*}$ \\
\hline Guizhou (dummy) & -0.327 & -0.670 & 0.369 & $3.268^{*}$ \\
\hline Yunnan (dummy) & -3.396 & $-6.183^{*}$ & 0.374 & $3.290^{\star}$ \\
\hline
\end{tabular}

Notes: - Estimates are for the $70^{\text {th }}$ quantile. ${ }^{*}$ indicates significance at $5 \%$ or lower level. - Standard errors reported in the above table are calculated from 60 bootstrap replication. - Left out categories in the above table are: Household with no children, proportion of kids in the ages $0-5$ years, proportion of adults with more than secondary school education, labor force in the household with more than middle-school education, proportion of kids who are illiterate, dummy for Guangxi province. 


\section{Policy Research Working Paper Series}

\begin{tabular}{|c|c|c|c|c|}
\hline & Title & Author & Date & $\begin{array}{l}\text { Contact } \\
\text { for paper }\end{array}$ \\
\hline WPS1911 & $\begin{array}{l}\text { The Internationalization of Financial } \\
\text { Services in Asia }\end{array}$ & $\begin{array}{l}\text { Stijn Claessens } \\
\text { Torn Glaessner }\end{array}$ & April 1998 & $\begin{array}{l}\text { R. Vo } \\
33722\end{array}$ \\
\hline WPS1912 & $\begin{array}{l}2 \text { Pay and Grade Differentials at the } \\
\text { World Bank }\end{array}$ & $\begin{array}{l}\text { Deon Filmer } \\
\text { Margaret Grosh } \\
\text { Elizabeth King } \\
\text { Dominique van de Walle }\end{array}$ & April 1998 & $\begin{array}{l}\text { C. Bernardo } \\
31148\end{array}$ \\
\hline WPS1913 & 3 The 1994 Currency Crisis in Turkey & Oya Celasun & April 1998 & $\begin{array}{l}\text { K. Labrie } \\
31001\end{array}$ \\
\hline WPS1914 & $\begin{array}{l}4 \text { Distinguishing between Types of } \\
\text { Data and Methods of Collecting Them }\end{array}$ & Jesko Hentschel & April 1998 & $\begin{array}{l}\text { PREM Advisory } \\
87736\end{array}$ \\
\hline WPS1915 & $\begin{array}{l}\text { Distortionary Effects of State Trading } \\
\text { in Agriculture: Issues for the Next } \\
\text { Round of Multilateral Trade } \\
\text { Negotiations }\end{array}$ & $\begin{array}{l}\text { Merlinda Ingco } \\
\text { Francis } \mathrm{Ng}\end{array}$ & April 1998 & $\begin{array}{l}\text { M. Fernandez } \\
33766\end{array}$ \\
\hline WPS1916 & $\begin{array}{l}\text { The Size, Origins, and Character } \\
\text { of Mongolia's Informal Sector } \\
\text { during the Transition }\end{array}$ & James $H$. Anderson & May 1998 & $\begin{array}{l}\text { P. Sintim-Aboagye } \\
37656\end{array}$ \\
\hline WPS1917 & $\begin{array}{l}7 \text { Financial Liberalization and Financial } \\
\text { Fragility }\end{array}$ & $\begin{array}{l}\text { Asli Demirgüç-Kunt } \\
\text { Enrica Detragiache }\end{array}$ & May 1998 & $\begin{array}{l}\text { P. Sintim-Aboagye } \\
37656\end{array}$ \\
\hline WPS1918 & $\begin{array}{l}\text { B How Does Foreign Entry Affect } \\
\text { the Domestic Banking Market? }\end{array}$ & $\begin{array}{l}\text { Stijn Claessens } \\
\text { Asli Demirgüç-Kunt } \\
\text { Harry Huizinga }\end{array}$ & May 1998 & $\begin{array}{l}\text { R. Vo } \\
33722\end{array}$ \\
\hline WPS1919 & $\begin{array}{l}\text { The Empirical Effects of Performance } \\
\text { Contracts: Evidence from China }\end{array}$ & $\begin{array}{l}\text { Mary Shirley } \\
\text { Lixin Colin Xu }\end{array}$ & May 1998 & $\begin{array}{l}\text { P. Sintim-Aboagye } \\
38526\end{array}$ \\
\hline WPS1920 & $\begin{array}{l}\text { Education and Earnings in a } \\
\text { Transition Economy (Vietnam) }\end{array}$ & $\begin{array}{l}\text { Peter R. Moock } \\
\text { Harry Anthony Patrinos } \\
\text { Meera Venkataraman }\end{array}$ & May 1998 & $\begin{array}{l}\text { M. Christian } \\
36736\end{array}$ \\
\hline WPS1921 & $\begin{array}{l}\text { Making Voice Work: The Report Card } \\
\text { on Bangalore's Public Service }\end{array}$ & Samuel Paul & May 1998 & $\begin{array}{l}\text { C. Bernardo } \\
31148\end{array}$ \\
\hline WPS1922 & $\begin{array}{l}2 \text { Regional Groupings Among } \\
\text { Microstates }\end{array}$ & $\begin{array}{l}\text { Soamiely Andriamananjara } \\
\text { Maurice Schiff }\end{array}$ & May 1998 & $\begin{array}{l}\text { L. Tabrada } \\
36896\end{array}$ \\
\hline WPS1923 & $\begin{array}{l}3 \text { When Vintage Technology Makes } \\
\text { Sense: Matching Imports to Skills }\end{array}$ & $\begin{array}{l}\text { Giorgio Barba Navaretti } \\
\text { Isidro Soloaga } \\
\text { Wendy Takacs }\end{array}$ & May 1998 & $\begin{array}{l}\text { L. Tabada } \\
36896\end{array}$ \\
\hline WPS1924 & $\begin{array}{l}4 \text { Voucher Privatization with } \\
\text { Investment Funds: An Institutional } \\
\text { Analysis }\end{array}$ & David Ellerman & May 1998 & $\begin{array}{l}\text { M. Murray } \\
36095\end{array}$ \\
\hline
\end{tabular}




\section{Policy Research Working Paper Series}

\begin{tabular}{|c|c|c|c|c|}
\hline & Title & Author & Date & $\begin{array}{l}\text { Contact } \\
\text { for paper }\end{array}$ \\
\hline WPS1925 & $\begin{array}{l}\text { Half a Century of Development } \\
\text { Economics: A Review Based on } \\
\text { the Handbook of Development } \\
\text { Economics }\end{array}$ & Jean Waelbroeck & May 1998 & $\begin{array}{l}\text { J. Sweeney } \\
31021\end{array}$ \\
\hline WPS 1926 & $\begin{array}{l}\text { Do Budgets Really Matter? } \\
\text { Evidence from Public Spending } \\
\text { on Education and Health in Uganda }\end{array}$ & $\begin{array}{l}\text { Emmanuel Ablo } \\
\text { Ritva Reinikka }\end{array}$ & June 1998 & $\begin{array}{l}\text { K. Rivera } \\
34141\end{array}$ \\
\hline NPS1927 & $\begin{array}{l}\text { Revenue-productive Income Tax } \\
\text { Structures and Tax Reforms in } \\
\text { Emerging Market Economies: } \\
\text { Evidence from Bulgaria }\end{array}$ & Fareed M. A. Hassan & June 1998 & $\begin{array}{l}\text { A. Panton } \\
85433\end{array}$ \\
\hline WPS1928 & $\begin{array}{l}\text { Combining Census and Survey Data } \\
\text { to Study Spatial Dimensions } \\
\text { of Poverty }\end{array}$ & $\begin{array}{l}\text { Jesko Hentschel } \\
\text { Jean OIson Lanjouw } \\
\text { Peter Lanjouw } \\
\text { Javier Poggi }\end{array}$ & June 1998 & $\begin{array}{l}\text { P. Lanjouw } \\
34529\end{array}$ \\
\hline MPS1929 & $\begin{array}{l}\text { A Database of World Infrastructure } \\
\text { Stccks, } 1950-95\end{array}$ & David Canning & June 1998 & $\begin{array}{l}\text { A. Abuzid } \\
33348\end{array}$ \\
\hline WP $\$ 1930$ & $\begin{array}{l}\text { The Main Determinants of Inflation in } \\
\text { Aibania }\end{array}$ & $\begin{array}{l}\text { Ilker Domac } \\
\text { Carlos Elbrit }\end{array}$ & June 1998 & $\begin{array}{l}\text { F. Lewis } \\
82979\end{array}$ \\
\hline WPS1931 & $\begin{array}{l}\text { The Cost and Performance of Paid } \\
\text { Agricultural Extenion Services: The } \\
\text { Case of Agricultural Technology } \\
\text { Transfer in Nicaragua }\end{array}$ & $\begin{array}{l}\text { Ariel Dinar } \\
\text { Gabriel Keynan }\end{array}$ & June 1998 & $\begin{array}{l}\text { F. Toppin } \\
30450\end{array}$ \\
\hline WeS 1932 & $\begin{array}{l}\text { Air Pollution and Health Effects: } \\
\text { A Study of Respiratory Illness } \\
\text { Among Children in Santiago, Chile }\end{array}$ & $\begin{array}{l}\text { Bart D. Ostro } \\
\text { Gunnar S. Eskeland } \\
\text { Tarhan Feyzioglu } \\
\text { Jose Miguel Sanchez }\end{array}$ & June 1998 & $\begin{array}{l}\text { C Bernardo } \\
31148\end{array}$ \\
\hline MPS1933 & The 1997 Pension Reform in Mexico & $\begin{array}{l}\text { Gloria Grandolini } \\
\text { Luis Cerda }\end{array}$ & June 1998 & $\begin{array}{l}\text { C. Zappala } \\
87945\end{array}$ \\
\hline MPS1934 & $\begin{array}{l}\text { WTO Accession for Countries } \\
\text { in Transition }\end{array}$ & Constantine Michalop & June 1998 & $\begin{array}{l}\text { L. Tabada } \\
36896\end{array}$ \\
\hline WPS1935 & $\begin{array}{l}\text { Explaining the Increase in Inequality } \\
\text { during the Transition }\end{array}$ & Branko Milanovic & June 1998 & $\begin{array}{l}\text { G. Evans } \\
85734\end{array}$ \\
\hline
\end{tabular}

